\title{
Latihan Senam dapat Menurunkan Kadar Glukosa Darah Pada Penderita Diabetes Melitus Tipe II
}

\author{
Rifa Fadhilah Lubis, Ramadya Kanzanabilla \\ Fakultas Kesehatan Masyarakat Universitas Indonesia \\ *Korespondensi: Rifa Fadhilah Lubis - lubisrifa@gmail.com
}

\begin{abstract}
Abstrak
Diabetes melitus tipe II adalah suatu keadaan hiperglikemia yang disebabkan gangguan pada resistensi insulin dan sekresi insulin sehingga metabolisme tubuh juga terganggu, merupakan masalah yang serius dan menjadi salah satu penyakit penyebab kematian yang cukup besar di Indonesia. Salah satu cara diabetes ini adalah dengan latihan fisik. Latihan fisik yang dianjurkan salah satunya adalah senam aerobik, yang bertujuan meningkatkan dan mempertahankan kesegaran tubuh dan dilaksanakan sesuai prinsip F.I.T.T (Frekuensi, Intensitas, Time dan Tipe). Penelitian ini bertujuan untuk menunjukkan dengan latihan senam secara rutin dapat mengontrol dan menurunkan kadar glukosa darah pada penderita diabetes melitus tipe II. Metode yang digunakan adalah kajian pustaka dari jurnal nasional dan internasional yang meneliti tentang pengaruh latihan senam terhadap penderita diabetes mellitus tipe II. Penelusuran jurnal ini menggunakan database Google Scholar, ReasearchGate, Pubmed, ScienceDirect. Hasil penelitian dari jurnal tersebut mununjukan dengan Latihan senam yang bersifat aerobik ditentukan oleh volume, intensitas, frekuensi dan pengulangan dapat mengurangi kadar glukosa darah hingga $30 \mathrm{mg} / \mathrm{dL}$, dengan rata-rata penurunan sekitar $2 \%$ dan frekuensi olahraga rutin minimal 3 kali seminggu dengan $\mathrm{P}=0,001$ dan $\mathrm{OR}=4,3$, jenis olahraga aerobik seperti senam dengan $\mathrm{P}=0,002$ dan $\mathrm{OR}=3,1$, serta durasi olahraga 30 menit per 1 kali olahraga dengan $\mathrm{P}=0,087$ dan $\mathrm{OR}=3,5$ berhubungan dengan kadar gula darah pada penderita diabetes melitus tipe 2. Sehingga diperlukannya melakukan latihan senam secara teratur untuk menurunkan dan mengkontrol kadar glukosa pada penderita diabetes mellitus tipe 2
\end{abstract}

Keyword: aktivitas fisik, diabetes melitus, glukosa darah, senam diabetes

\section{Exercise Can Reduce Blood Glucose Levels in Type II Diabetes Mellitus Patients}

\begin{abstract}
Type II diabetes mellitus is a condition of hyperglycemia caused by disturbances in insulin resistance and insulin secretion so that the body's metabolism is also disturbed, is a serious problem and is one of the major causes of death in Indonesia. One of the ways diabetes is with physical exercise. One of the recommended physical exercises is aerobic exercise, which aims to improve and maintain body freshness and is carried out according to the principles of F.I.T.T (Frequency, Intensity, Time and Type). This study aims to show that regular exercise can control and reduce blood glucose levels in patients with type II diabetes mellitus. The method used is a literature review from national and international journals that examines the effect of gymnastics on patients with type II diabetes mellitus. This journal search uses Google Scholar, ReasearchGate, Pubmed, ScienceDirect databases. The results of the study from the journal show that aerobic exercise determined by volume, intensity, frequency and repetition can reduce blood glucose levels up to $30 \mathrm{mg} / \mathrm{dL}$, with an average decrease of about $2 \%$ and the frequency of regular exercise at least 3 times a week with $P=0.001$ and $O R=4.3$, types of aerobic exercise such as gymnastics with $P=0.002$ and $O R=3.1$, and exercise duration of 30 minutes per 1 exercise with $P=0.087$ and $O R=3.5$ associated with blood sugar levels in patients with type 2 diabetes mellitus, so that it is necessary to do regular exercise to reduce and control glucose levels in patients with type 2 diabetes mellitus
\end{abstract}

Keywords: physical activity, diabetes mellitus, blood glucose, diabetes exercise 


\section{PENDAHULUAN}

Diabetes melitus (DM) adalah penyakit kronis yang terjadi karena pankreas tidak menghasilkan cukup insulin, atau ketika tubuh tidak dapat secara efektif menggunakan insulin yang dihasilkannya. Diabetes melitus sering disebut dengan "Silent Killer" dikarenakan penyakit ini dapat membunuh seseorang secara perlahan atau diam-diam. Diperkirakan, 1,6 juta kematian secara langsung disebabkan oleh diabetes secara global (1).

\section{Menurut International Diabetes} Federation (IDF) tahun 2017, tingkat prevalensi global penderita diabetes melitus di Asia Tenggara adalah sebesar 8,5\% pada kelompok usia 20-79 tahun, dimana Indonesia menempati urutan ke-6 setelah Cina, India, Amerika Serikat, Brazil, dan Mexico dengan jumlah penderita diabetes melitus sebesar 10,3 juta (2). Sedangkan menurut Kementerian Kesehatan Republik Indonesia (2018), prevalensi penyakit diabetes melitus di Indonesia naik dari 6,9\% menjadi 8,5\% dengan DKI Jakarta menempati urutan pertama prevalensi tertinggi penderita diabetes melitus di Indonesia yaitu sebesar 3,4\% (3).

Penatalaksanaan diabetes melitus serta pencegahan komplikasi adalah tantangan penting saat ini, Salah satu faktor terjadinya diabetes melitus adalah gaya hidup tidak sehat yang bisa diatasi dengan latihan fisik. Latihan fisik yang dapat dilakukan antara lain latihan berjalan, jogging, berenang, bersepeda, dan senam. Paling tidak 3 kali seminggu setiap 15 sampai 60 menit sampai berkeringat (4). Selain itu menurut Colberg (2010), aktivitas fisik harus dilakukan minimal sebanyak tiga kali dalam seminggu dikarenakan efek dari sekali berolahraga sesuai anjuran terhadap sensitivitas insulin hanya dapat bertahan selama 24 hingga 72 jam (5).

Masalah utama pada diabetes melitus tipe II adalah kurangnya respons reseptor terhadap insulin karena adanya gangguan tersebut insulin tidak dapat membantu transfer glukosa ke dalam sel. Gaya hidup kurang melakukan aktivitas fisik, juga turut mempengaruhi patogenesis kegagalan dalam toleransi glukosa. Maka dari itu, pengontrolan gula darah merupakan cara yang dapat dilakukan. Dengan mengontrol kadar glukosa agar stabil dan tetap berada pada batas yang aman, akan berdampak pada peningkatan kualitas hidup pada penderita diabetes melitus dan dapat dilakukan sebagai upaya pengendalian penyakit diabetes melitus (6).

Dengan melakukan aktivitas fisik, akan mempengaruhi kadar glukosa dalam darah. Ketika aktivitas tubuh tinggi, penggunaan glukosa oleh otot akan ikut meningkat. Sintesis glukosa endogen akan ditingkatkan untuk menjaga agar kadar glukosa dalam darah tetap seimbang. Pada 
keadaan normal, keadaan homeostasis ini dapat dicapai oleh berbagai mekanisme dari sistem hormonal, saraf, dan regulasi glukosa. Ketika tubuh tidak dapat mengkompensasi kebutuhan glukosa yang tinggi akibat aktivitas fisik yang berlebihan, maka kadar glukosa tubuh akan menjadi terlalu rendah (hipoglikemia) (7).

Sebaliknya, jika kadar glukosa darah melebihi kemampuan tubuh untuk menyimpannya disertai dengan aktivitas fisik yang kurang, maka kadar glukosa darah menjadi lebih tinggi dari normal (hiperglikemia). Maka dari itu, saat melakukan aktivitas fisik seperti senam bagi penderita diabetes, glukosa darah akan dibakar menjadi energi. Sehingga sel energi menjadi lebih sensitif terhadap insulin dan peredaran darah menjadi lebih baik (7). Penelitian ini bertujuan untuk memaparkan bahwa dengan latihan senam secara rutin dapat menurunkan kadar glukosa darah pada penderita diabetes melitus tipe II.

\section{METODE}

Metode penelitian menggunakan literature review dengan melakukan penelusuran sumber seperti jurnal nasional maupun internasional dengan penelitianpenelitian sebelumnya mengenai kejadian Diabetes Melitus tipe II dengan latihan senam secara rutin bisa mengkontrol kadar glukosa darah. Penelusuran sumber digunakan dengan menggunakan mesin pencari Google Scholar, ReasearchGate, Pubmed, ScienceDirect. Kata kunci yang digunakan senam diabates, glukosa darah, diabetes melitus, blood sugar levels, exercise, physical activity. Sumber pustaka yang dipilih terbatas pada waktu publikasi yang tidak lebih dari 10 tahun serta menggunakan bahasa Indonesia dan juga Bahasa Inggris.

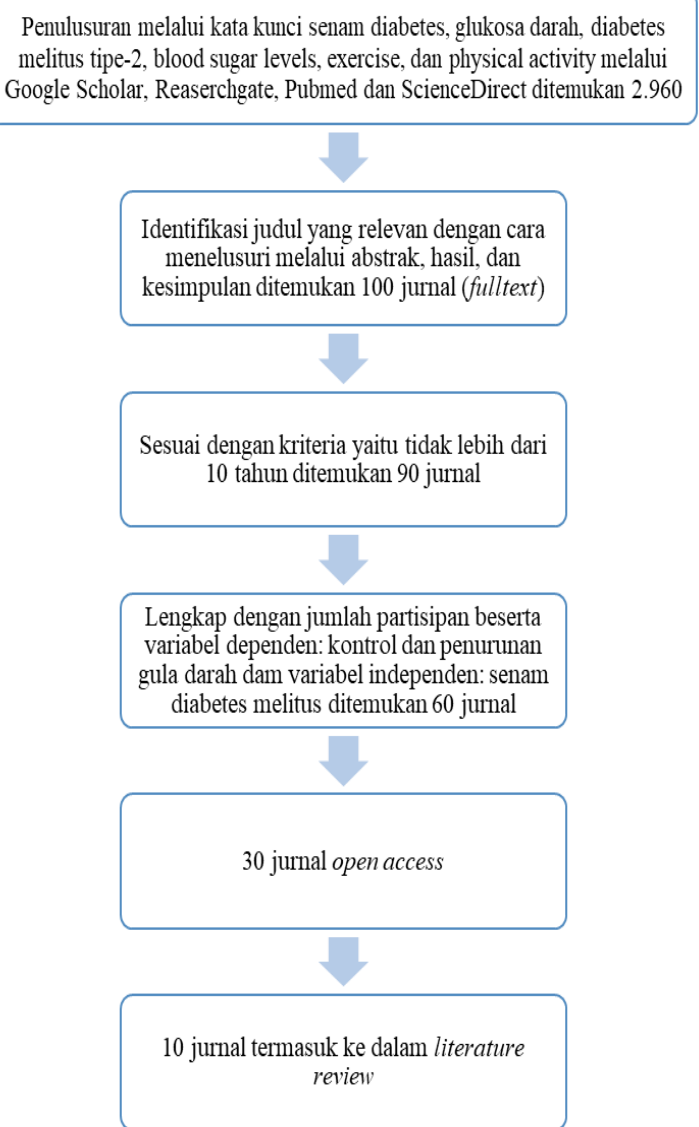

Gambar 1. Alur Pemilian Literatur

\section{HASIL}

Diabetes Melitus (DM) adalah kondisi peningkatan kadar gula dalam darah diatas normal. Dikatakan diabetes melitus jika, kadar gula darah sewaktu (GDS) >200 
mg/dL dan kadar gula darah puasa (GDP) $>126 \mathrm{mg} / \mathrm{dL}$ (8). Pada penderita diabetes, pankreas tidak mampu memproduksi insulin sesuai kebutuhan tubuh. Tanpa adanya insulin, sel-sel tubuh tidak dapat menyerap dan mengubah glukosa menjadi energi. Diabetes yang tidak terkontrol dapat menyebabkan penyakit jantung, stroke, kebutaan, dan gagal ginjal (9).

Menurut Direktorat Pencegahan dan Pengendalian Penyakit Tidak Menular (2017), diabetes tipe 2 adalah kondisi dimana pankreas tidak menghasilkan insulin yang memadai atau tubuh tidak mampu menggunakan insulin yang tersedia. Keadaan ini disebut resistensi insulin. Resistensi insulin banyak terjadi akibat dari obesitas dan kurangnya aktivitas fisik $(10,11)$.

Beberapa faktor terjadinya diabetes tipe 2 diantaranya, pertama adalah riwayat keluarga. Jika seseorang memiliki orangtua atau saudara kandung dengan diabetes tipe 2, maka risiko mendapatkan diabetes menjadi meningkat (10).

Pada DM tipe 2, jika salah satu anggota keluarga mengalami diabetes, anggota keluarga yang lain memiliki risiko yang lebih tinggi untuk menderita diabetes. Jika pada DM tipe 1 hanya 50\% risiko terkena diabetes jika memiliki saudara kembar yang menderita diabetes. Maka pada DM tipe 2, risiko tersebut dapat meningkat hingga 90\% (12). Kedua adalah usia lebih dari 40 tahun akan meningkatkan risiko diabetes tipe 2. Hal ini berhubungan dengan penurunan aktivitas fisik, kehilangan massa otot, dan bertambahnya berat badan (10).

Hal ini sejalan dengan yang dikemukan oleh Arisman (2011), risiko terjadinya diabetes melitus tipe 2 bertambah seiring dengan pertambahan umur, karena sel beta yang produktif berkurang seiring pertambahan umur. Dibandingkan dengan usia yang lebih muda, usia diatas 45 tahun akan mengalami peningkatan insulin dari hati (hepatic glucose production) dan cenderung akan mengalami retensi insulin serta gangguan sekresi insulin akibat penuaan dan apoptosis sel beta pankreas (13).

Bagi usia diatas 45 tahun dengan indeks massa tubuh normal (IMT) yaitu 18.5-25.0, gangguan akan lebih banyak pada sekresi insulin di sel beta pankreas. Sedangkan, bagi usia diatas 45 tahun yang obesitas dengan indeks massa tubuh (IMT) $>27$, gangguan lebih banyak pada resistensi insulin di jaringan perifer seperti otot, sel hati, dan sel lemak (adiposit) (13). Ketiga adalah kegemukan atau obesitas. Kelebihan berat badan akan meningkatkan kebutuhan insulin pada tubuh. Orang dewasa yang kegemukan memiliki sel-sel lemak yang lebih besar pada tubuh dan sel-sel lemak yang lebih besar ini akan membuat insulin tidak merespons dengan baik (14). 
Terakhir adalah aktivitas fisik yang tidak memadai atau kurangnya berolahraga. Dengan melakukan olahraga, akan membantu tubuh untuk meningkatkan sensitivitas sel terhadap insulin (10). Menurut Sipayung (2018), aktivitas fisik ringan seperti memasak, melakukan perawatan diri, mengemudi mobil, menonton tv, dan duduk memiliki peluang risiko 6,2 kali lebih besar menderita diabetes melitus tipe 2 dibandingkan aktivitas fisik sedang dan berat seperti aerobik intensitas sedang yaitu berenang, jogging, senam, dan bersepeda (15).

Olahraga merupakan gerakan olah tubuh yang memberikan efek secara keseluruhan. Olahraga membantu merangsang otot-otot dan bagian tubuh lainnya untuk bergerak. Otot-otot menjadi terlatih serta sirkulasi darah dan oksigen dalam tubuh menjadi lancar sehingga metabolisme tubuh menjadi optimal (16). Menurut Riyadi (2008), olahraga dapat menjaga kebugaran, menurunkan berat badan, serta memperbaiki sensitivitas insulin, sehingga akan memperbaiki kendali glukosa darah. Olahraga teratur yaitu 3-5 kali seminggu selama kurang lebih 30-60 menit akan memperbaiki sirkulasi insulin dengan cara meningkatkan dilatasi sel dan pembuluh darah sehingga membantu masuknya glukosa ke dalam sel (17).

Olahraga mempunyai banyak jenis, salah satunya adalah senam. Senam merupakan olahraga yang populer di masyarakat dikarenakan mudah, murah, dan menyenangkan. Saat melakukan olahraga senam, hampir seluruh bagian tubuh bergerak. Pergerakkan terjadi pada otot-otot tangan, kaki, dan pinggul. Pada saat bergerak terjadi peningkatan laju pernafasan dan denyut jantung yang menyebabkan kadar oksigen didarah meningkat dan pembuluh darah membesar. Perubahan-perubahan metabolisme ini akan memberikan dampak positif yang bermanfaat untuk tubuh. Selain itu, senam juga membantu menjaga berat badan, meningkatkan stamina, membantu mengontrol gula darah, dan mengurangi stress (16).

Tabel 1. Hasil Observasi Elemen Input, Proses, dan Output pada Penggunaan Aplikasi Silacak di UPT Puskesmas Cipadung

\begin{tabular}{|c|c|c|c|c|}
\hline No & Judul Penelitian & $\begin{array}{c}\text { Nama Peneliti, } \\
\text { Tahun }\end{array}$ & $\begin{array}{c}\text { Metode } \\
\text { Penelitian \& } \\
\text { Besar sampel }\end{array}$ & Hasil \\
\hline 1. & $\begin{array}{l}\text { Effects of an Aerobic } \\
\text { Physical Exercise Program } \\
\text { on Blood Glucose Levels in } \\
\text { Type-2 Diabetic Subjects, } \\
\text { Associated with } \\
\text { Pharmacotherapy and Diet } \\
\text { Therapy }\end{array}$ & $\begin{array}{l}\text { Helio Almeida, } \\
\text { Leonardo Neto, } \\
\text { Fátima Queiroga, } \\
\text { José Souza, Carlos } \\
\text { Chaves, Jonatas } \\
\text { Barros (2020) (18) }\end{array}$ & $\begin{array}{l}\text { Pra eksperimen } \\
\text { dengan } \\
\text { rancangan One } \\
\text { Group pretest } \\
\text { and post test } \\
\text { Design \& } 39 \\
\text { partisipan }\end{array}$ & $\begin{array}{c}\text { Latihan aktivitas fisik } \\
\text { yang ditentukan oleh volume, } \\
\text { intensitas, } \\
\text { frekuensi dan pengulangan } \\
\text { dapat mengurangi kadar } \\
\text { glukosa darah dari } 145.88 \\
\mathrm{mg} / \mathrm{dL} \text { menjadi } 116.35 \mathrm{mg} / \mathrm{dL}\end{array}$ \\
\hline
\end{tabular}




\begin{tabular}{|c|c|c|c|c|}
\hline No & Judul Penelitian & $\begin{array}{c}\text { Nama Peneliti, } \\
\text { Tahun }\end{array}$ & $\begin{array}{c}\text { Metode } \\
\text { Penelitian \& } \\
\text { Besar sampel }\end{array}$ & Hasil \\
\hline 2. & $\begin{array}{l}\text { Effect of aerobic exercise } \\
\text { intensity on glycemic } \\
\text { control in type } 2 \text { diabetes: a } \\
\text { meta-analysis of head-to- } \\
\text { head randomized trials }\end{array}$ & $\begin{array}{c}\text { Yilina } \\
\text { Liubaoerjijin, } \\
\text { Tasuku Terada, } \\
\text { Kevin Fletcher, } \\
\text { Normand G. Boule } \\
\text { (2016) (19) }\end{array}$ & $\begin{array}{c}\text { Study Literature } \\
\& 235 \text { orang } \\
\text { partisipan }\end{array}$ & $\begin{array}{c}\text { Pada penderita diabetes tipe } 2, \\
\text { penurunan HbA1c sebanyak } \\
0,67 \% \text { dihasilkan dengan } \\
\text { latihan aerobik high intensity }\end{array}$ \\
\hline 3. & $\begin{array}{l}\text { Association between } \\
\text { Aerobic Capacity and the } \\
\text { Improvement in Glycemic } \\
\text { Control After the Exercise } \\
\text { Training in Type } 2 \text { Diabetes }\end{array}$ & $\begin{array}{c}\text { Hideki Nojima, } \\
\text { Masayasu Yoneda, } \\
\text { Hiroshi Watanabe, } \\
\text { Kiminori Yamane, } \\
\text { Yoshihiro } \\
\text { Kitahara, Kiyokazu } \\
\text { Sekikawa, Hideya } \\
\text { Yamamoto, } \\
\text { Akihito } \\
\text { Yokoyama, } \\
\text { Noboru Hattori, } \\
\text { Nobuoki Kohno } \\
\text { (2017) (20) }\end{array}$ & $\begin{array}{c}\text { Pre Eksperimen } \\
\& 62 \text { partisipan } \\
\text { laki-laki }\end{array}$ & $\begin{array}{c}\text { Tingkat kapasitas aerobik pada } \\
\text { pasien diabetes tipe } 2 \\
\text { mempengaruhi perubahan } \\
\text { glycated albumin (GA) dari } \\
23,5 \% \text { menjadi } 21,7 \%\end{array}$ \\
\hline 4. & $\begin{array}{l}\text { Exercise Training } \\
\text { Modalities in Patients with } \\
\text { Type } 2 \text { Diabetes Mellitus: A } \\
\text { Systematic } \\
\text { Review and Network Meta- } \\
\text { analysis }\end{array}$ & $\begin{array}{c}\text { Bei Pan, Long Ge, } \\
\text { Yang Xun, Ya-jing } \\
\text { Chen, Cai-yun } \\
\text { Gao1, Xue Han, } \\
\text { Li-qian Zuo, Hou- } \\
\text { qian Shan (2018) } \\
(21)\end{array}$ & $\begin{array}{l}\text { Systematic } \\
\text { Review and } \\
\text { Meta-analysis } \\
\& 2208 \\
\text { partisipan }\end{array}$ & $\begin{array}{l}\text { Latihan kombinasi ketahanan } \\
\text { dan kekuatan menunjukkan } \\
\text { peningkatan lebih tinggi untuk } \\
\text { penurunan HbA1c sebanyak } \\
0,60 \% \text { dibandingkan dengan } \\
\text { latihan aerobik biasa }\end{array}$ \\
\hline 5. & $\begin{array}{l}\text { Efektivitas Senam Diabetes } \\
\text { terhadap Kadar Gula Darah } \\
\text { pada Pasien diabetes } \\
\text { mellitus di Lamongan }\end{array}$ & $\begin{array}{l}\text { Ike Prafita Sari, } \\
\text { Masnif Effendi } \\
(2020)(22)\end{array}$ & $\begin{array}{l}\text { Pra eksperimen } \\
\text { dengan } \\
\text { rancangan One } \\
\text { Group pretest } \\
\text { and post test } \\
\text { Design \& } 39 \\
\text { partisipan }\end{array}$ & $\begin{array}{l}\text { Terdapat penurunan kadar gula } \\
\text { darah antara sebelum diberikan } \\
\text { senam diabetes dan sesudah } \\
\text { diberikan senam diabetes, dari } \\
247 \mathrm{mg} / \mathrm{dL} \text { menjadi } 225 \\
\mathrm{mg} / \mathrm{dL} \text {. Sehingga, senam } \\
\text { efektif untuk menurunkan } \\
\text { kadar gula darah pada pasien } \\
\text { diabetes melitus di Lamongan }\end{array}$ \\
\hline 6. & $\begin{array}{l}\text { The Effect of } 12 \text { Weeks } \\
\text { Aerobic, Resistance, and } \\
\text { Combined Exercises on } \\
\text { Omentin-1 Level and } \\
\text { Insulin Resistance among } \\
\text { Type } 2 \text { Diabetic Middle- } \\
\text { Aged Women }\end{array}$ & $\begin{array}{c}\text { Zeinab AminiLari, } \\
\text { Mohammad } \\
\text { Fararoei, Sasan } \\
\text { Amanat, Ehsan } \\
\text { Sinae, Safa } \\
\text { Dianatinasab, } \\
\text { Mahmood } \\
\text { AminiLari, Nima } \\
\text { Daneshi, Mostafa } \\
\text { Dianatinasab } \\
\text { (2016) (23) }\end{array}$ & $\begin{array}{l}\text { Randomised } \\
\text { Controlled Trial } \\
\text { Study \& } 60 \\
\text { partisipan } \\
\text { wanita berusia } \\
45-60 \text { tahun }\end{array}$ & $\begin{array}{c}\text { Dilakukan pengamatan pada } \\
\text { tiga kelompok berbeda yaitu } \\
\text { kelompok yang melakukan } \\
\text { latihan aerobik } 5 \text { kali } \\
\text { seminggu, kelompok yang } \\
\text { melakukan latihan beban, dan } \\
\text { kelompok yang melakukan } \\
\text { latihan kombinasi ketahanan } \\
\text { dan kekuatan. } \\
\text { Perubahan kadar omentin-1 } \\
\text { paling besar dari } 31,90 \mathrm{ng} / \mathrm{mL} \\
\text { menjadi } 48,82 \text { ng/mL selama } \\
12 \text { minggu terjadi pada } \\
\text { kelompok latihan kombinasi } \\
\text { ketahanan dan kekuatan. }\end{array}$ \\
\hline
\end{tabular}




\begin{tabular}{|c|c|c|c|c|}
\hline No & Judul Penelitian & $\begin{array}{c}\text { Nama Peneliti, } \\
\text { Tahun }\end{array}$ & $\begin{array}{c}\text { Metode } \\
\text { Penelitian \& } \\
\text { Besar sampel }\end{array}$ & Hasil \\
\hline 7. & $\begin{array}{l}\text { Association Between } \\
\text { Physical Activity and } \\
\text { Diabetic Complications } \\
\text { among Bangladesh Type } 2 \\
\text { Diabetic Patients }\end{array}$ & $\begin{array}{l}\text { Mohammad Sadaat } \\
\text { Bukht, Kazi } \\
\text { Rumana Ahmed, } \\
\text { Sahadat Hossain, } \\
\text { Parisha Masud, } \\
\text { Shuhana Sultana, } \\
\text { Rasheda Khanam } \\
\text { (2018) (24) }\end{array}$ & $\begin{array}{c}\text { Cross Sectional } \\
\& 977 \\
\text { partisipan }\end{array}$ & $\begin{array}{l}\text { Kurang melakukan aktivitas } \\
\text { fisik berakibat pada } \\
\text { peningkatan obesitas serta } \\
\text { berisiko terkena diabetes } \\
\text { melitus tipe } 2 \text { dengan } \mathrm{P}=0,001 \\
\text { dan } \mathrm{OR}=0,72\end{array}$ \\
\hline 8. & $\begin{array}{l}\text { Upaya Peningkatan Kualitas } \\
\text { Hidup Penderita DM } \\
\text { dengan Memberikan } \\
\text { Pelatihan Senam Diabetes }\end{array}$ & $\begin{array}{c}\text { Yusran Haskas, } \\
\text { Sitti Nurbaya } \\
\text { (2019) (25) }\end{array}$ & $\begin{array}{c}\text { Pre eksperimen } \\
\text { dengan } \\
\text { memberikan } \\
\text { perlakuan pada } \\
\text { subjek } \\
\text { penelitian \& } 42 \\
\text { partisipan }\end{array}$ & $\begin{array}{c}\text { Senam diabetes dapat } \\
\text { membantu penderita diabetes } \\
\text { melitus dalam mengontrol } \\
\text { kadar glukosa darah sewaktu } \\
\text { dari } 226.14 \mathrm{mg} / \mathrm{dL} \text { menjadi } \\
216.90 \mathrm{mg} / \mathrm{dL}\end{array}$ \\
\hline 9. & $\begin{array}{l}\text { Hubungan antara Kebiasaan } \\
\text { Olahraga dengan Kadar } \\
\text { Gula Darah Penderita } \\
\text { Diabetes Mellitus Tipe } 2\end{array}$ & $\begin{array}{l}\text { Fany Fanana } \\
\text { Mahdia, Henry } \\
\text { Setyawan Susanto, } \\
\text { M. Sakundarno } \\
\text { Adi (2018) (26) }\end{array}$ & $\begin{array}{l}\text { Cross Sectional } \\
\& 80 \text { partisipan }\end{array}$ & $\begin{array}{c}\text { Frekuensi olahraga rutin } \\
\text { minimal } 3 \text { kali seminggu } \\
\text { dengan } \mathrm{P}=0,001 \text { dan } \mathrm{OR}=4,3 \text {; } \\
\text { jenis olahraga ketahanan } \\
\text { seperti senam dan jalan kaki } \\
\text { dengan } \mathrm{P}=0,002 \text { dan } \mathrm{OR}=3,1 \text {; } \\
\text { serta durasi olahraga } 30 \text { menit } \\
\text { per } 1 \text { kali olahraga dengan } \\
\mathrm{P}=0,087 \text { dan OR=3,5 } \\
\text { berhubungan dengan kadar } \\
\text { gula darah pada penderita } \\
\text { diabetes melitus tipe } 2\end{array}$ \\
\hline 10. & $\begin{array}{l}\text { Pengaruh Senam Aerobik } \\
\text { Low Impact Terhadap Gula } \\
\text { Darah Puasa pada Klien } \\
\text { Diabetes Mellitus }\end{array}$ & $\begin{array}{l}\text { Evangeline H, } \\
\text { Galih Jatnika, } \\
\text { Sulastri Nurhartini } \\
\quad(2018)(27)\end{array}$ & $\begin{array}{c}\text { Pre eksperimen } \\
\text { dengan } \\
\text { memberikan } \\
\text { perlakuan pada } \\
\text { subjek } \\
\text { penelitian \& } 10 \\
\text { partisipan }\end{array}$ & $\begin{array}{l}\text { Adanya perbedaan bermakna } \\
\text { antara kadar glukosa darah } \\
\text { puasa pada responden sebelum } \\
\text { dan setelah mengikuti senam } \\
\text { aerobik. Rerata kadar glukosa } \\
\text { darah puasa sebelum senam } \\
\text { adalah } 81,66 \mathrm{mg} / \mathrm{dl}, \text { sedangkan } \\
\text { rerata kadar glukosa darah } \\
\text { setelah senam adalah } 67,81 \\
\mathrm{mg} / \mathrm{dl} .\end{array}$ \\
\hline
\end{tabular}

\section{PEMBAHASAN}

Dari hasil tinjauan 10 jurnal yang dikumpulkan, yang terdiri dari 6 jurnal Bahasa Inggris dan 4 Jurnal Bahasa Indonesia, didapatkan bahwa olahraga yang disarankan untuk menurunkan kadar glukosa darah pada penderita diabetes melitus tipe 2 adalah latihan aerobik seperti senam. Senam diabetes merupakan senam fisik yang dirancang menurut usia dan status fisik yang merupakan bagian dari pengobatan diabetes melitus. Senam diabetes melitus dilakukan secara teratur selama 30-60 menit sebanyak 3-5 kali dalam seminggu latihan fisik secara teratur dapat menurunkan kadar HbA1c (25).

Anjuran dokter kepada pasien dengan pre-diabetes dan dengan kadar glukosa 
normal untuk meningkatkan latihan fisik masing-masing sebesar $59.1 \%$ dan $24.2 \%$. Nilai physical activity ratio (PAR) untuk setiap aktivitas mengacu pada panduan World Health Organization (WHO) mengenai human energy requirement yaitu menghitung kebutuhan energi dengan besarnya aktivitas fisik yang dilakukan. Besarnya aktivitas fisik yang dilakukan selama 24 jam dinyatakan dalam physical activity level (PAL) yang dibagi menjadi tiga kelompok yaitu kelompok aktivitas ringan ( $\mathrm{PAL}=1.40-1.69)$, aktivitas sedang (PAL=1.70-1.99), dan aktivitas berat $(\mathrm{PAL}=2.00-2.40)$.

Menurut penelitian Sari (2020), dengan melakukan senam secara teratur akan memberikan beberapa manfaat diantaranya, mengontrol gula darah terutama bagi penderita diabetes tipe 2 . Menurut penelitian, terdapat penurunan kadar gula darah antara sebelum dan sesudah diberikan senam diabetes dari 247 $\mathrm{mg} / \mathrm{dL}$ menjadi $225 \mathrm{mg} / \mathrm{dL}$, dikarenakan saat melakukan senam, glukosa darah akan dibakar menjadi energi sehingga sel-sel energi menjadi lebih sensitif terhadap insulin dan peredaran darah lebih baik serta risiko terjadinya diabetes tipe 2 akan turun menjadi 50\% (7).

Kedua adalah memperbaiki profil lemak darah dan menurunkan kadar kolestrol total, ketiga adalah menurunkan berat badan dikarenakan pengaturan olahraga secara optimal dapat membantu mengurangi berat badan dan penurunan berat badan dapat bermanfaat untuk memperbaiki resisten insulin, mengontrol gula darah, serta memperbaiki risiko penyakit jantung koroner, dan yang terakhir adalah mengurangi tingkat stress dan rasa cemas bagi penderita diabetes melitus tipe 2 (7).

Hal ini sejalan dengan penelitian Bukht (2019), bahwa terdapat hubungan yang bermakna antara aktivitas fisik dengan terjadinya komplikasi pada diabetes tipe 2 dengan $\mathrm{P}=0.05$. Dikarenakan, sejalan dengan penurunan aktivitas fisik, prevalensi obesitas meningkat secara signifikan, dan penderita diabetes melitus tipe 2 juga mengalami kenaikan (24).

Menurut penelitian AminiLari (2017), kadar glukosa menurun setelah 12 minggu dilakukan latihan beban, latihan kombinasi ketahanan dan kekuatan, serta latihan dengan frekuensi 5 kali seminggu. Latihan kombinasi ini bisa dilakukan dengan aktivitas senam (23). Hal ini sejalan dengan penelitian Pan (2018), bahwa latihan kombinasi ketahanan dan kekuatan efektif untuk mengurangi $\mathrm{HbA1C}$ pada penderita diabetes melitus. Namun, latihan kombinasi ketahanan dan kekuatan lebih efektif jika dilakukan dengan pengawasan untuk memantau frekuensi dan durasi yang sesuai (21). 
Menurut penelitian Mahdia (2018), frekuensi olahraga terbukti berhubungan dengan kadar gula darah pada penderita diabetes melitus tipe 2 dengan $\mathrm{P}=0,001$. Senam yang dilakukan tiga kali dalam seminggu akan meningkatkan kerja insulin pada penderita diabetes melitus tipe 2 . Permeabilitas otot juga akan meningkat dan reseptor insulin menjadi lebih banyak dan lebih peka. Selain itu, durasi senam terbukti berhubungan dengan kadar gula darah pada penderita diabetes mellitus tipe 2 dengan nilai $\mathrm{P}=0,015$. Senam yang dilakukan minimal tiga kali seminggu dengan durasi minimal 30 menit akan meningkatkan sensitivitas insulin (26).

\section{KESIMPULAN}

Dari semua jurnal yang telah direview dapat disimpulkan bahwa jenis olahraga yang dianjurkan untuk penderita diabetes mellitus tipe II adalah olahraga yang bersifat aerobik (endurance), seperti senam. Hasil penelitian diperoleh bahwa dengan latihan senam yang ditentukan oleh volume, intensitas, frekuensi dan pengulangan dapat mengurangi kadar glukosa darah hingga 30 $\mathrm{mg} / \mathrm{dL}$, dengan rata-rata penurunan sekitar $2 \%$ dan jenis olahraga (aerobik) dengan $\mathrm{P}=0,002$ dan $\mathrm{OR}=3,1$. Frekuensi menunjukkan banyaknya olahraga persatuan waktu, dengan olahraga rutin minimal 3 kali seminggu dengan $\mathrm{P}=0,001$ dan $\mathrm{OR}=4,3$ serta durasi olahraga 30 menit per 1 kali olahraga dengan $\mathrm{P}=0,087$ dan $\mathrm{OR}=3,5$ terbukti berhubungan dengan kadar gula darah pada penderita diabetes melitus tipe 2 yang dapat menurunkan dan mengontrok kadar glukosa darah tetap normal.

Saran kepada pemerintah yaitu diharapkan lebih rutin memfasilitasi kegiatan penyuluhan pada penderita diabetes mellitus tipe II seperti pemeriksaan gula darah dan latihan senam bersama seperti di car free day, mall dan lainnya dan mengadakan kegiatan lomba senam yang diharapkan dapat meningkatkan semangat dan antuasisme dalam mengikuti latihan senam.

Saran kepada petugas kesehatan yaitu diharapkan dapat meningkatkan kepatuhan pada penderita diabetes mellitus untuk mengikuti kegiatan latihan senam sebagai salah satu penatalaksanaan untuk mencegah kompikasi dengan menerapkan jadwal rutin untuk senam, memfasilitasi untuk melakukan senam seperti di halaman puskesmas, dan menyediakan pelatih untuk senam.

Saran kepada penderita diabetes melitus yaitu dapat melaksanakan latihan senam secara rutin dimulai dari intensitas ringan terlebih dahulu lalu dilanjutkan ke intensitas sedang dan berat. Latihan tidak dianjurkan untuk dilakukan selama masa 
kerja insulin berada di puncak karena dapat menyebabkan terjadinya hipoglikemia.

\section{DAFTAR PUSTAKA}

1. WHO. Global Report on Diabetes. WHO. Geneva; 2016.

2. International Diabetes Federation. IDF Diabetes Atlas. Eight. Brussel: International Diabetes Federation; 2017.

3. Kementerian Kesehatan RI. Laporan Nasional Riskesdas 2018. Lap Nas RIskesdas 2018. 2018;

4. Windartik E, Lestari I, Sulistiyo A. Upaya Menurunkan Kadar Gula Darah pada Penderita Diabetes Mellitus (DM) dengan Senam DM. Adi Husada Nurs J. 2016;2(2):27-31.

5. Colberg SR, Sigal RJ, Fernhall B, Regensteiner JG, Blissmer BJ, Rubin $\mathrm{RR}$, et al. Exercise and type 2 diabetes: the American College of Sports Medicine and the American Diabetes Association: joint position statement executive summary. Diabetes Care. 2010;33(12):2692-6.

6. Putri NHK, Isfandiari MA. Hubungan Empat Pilar Pengendalian DM Tipe 2 dengan Rerata Kadar Gula Darah. J Berk Epidemiol. 2013;1(2):234-43.

7. Purnama A, Sari N. Aktivitas Fisik dan Hubungannya dengan Kejadian Diabetes Mellitus. Wind Heal J
Kesehat. 2019;2(4):368-81.

8. Kementrian Kesehatan RI. Yuk, mengenal apa itu penyakit Diabetes Melitus (DM) - Direktorat P2PTM [Internet]. Kementrian Kesehatan RI. 2020 [cited 2020 Oct 4]. Available from:

http://www.p2ptm.kemkes.go.id/info graphic-p2ptm/penyakit-diabetesmelitus/page/4/yuk-mengenal-apaitu-penyakit-diabetes-melitus-dm

9. National Institute of Diabetes and Digestive and Kidney Disease. What is Diabetes? [Internet]. National Institute of Diabetes and Digestive and Kidney Disease. 2016 [cited 2020 Oct 4]. Available from: https://www.niddk.nih.gov/healthinformation/diabetes/overview/whatis-diabetes

10. Kementrian Kesehatan RI. Diabetes Tanya-Jawab seputar. Jakarta: Kementrian Kesehatan RI; 2016.

11. Harding A-H, Day NE, Khaw K-T, Bingham S, Luben R, Welsh A, et al. Dietary fat and the risk of clinical type 2 diabetes: the European prospective investigation of Cancer-Norfolk study. Am J Epidemiol. 2004;159(1):73-82.

12. Codario RA. Type 2 Diabetes, PreDiabetes, and the Metabolic Syndrome. Type 2 Diabetes, PreDiabetes, Metab Syndr. 2011; 
13. Arisman. Obesitas diabetes mellitus dan dislipidemia: Konsep teori dan penanganan aplikatif. cet. 04. Jakarta: EGC; 2011.

14. Suwinawati E, Ardiani H, Ratnawati R. Hubungan Obesitas dengan Kejadian Diabetes Melitus Tipe 2 Di Pos Pembinaan Terpadu Penyakit Tidak Menular Puskesmas Kendal Kabupaten Ngawi. J Heal Sci Prev. 2020;4(2):79-84.

15. Sipayung R, Siregar FA, Nurmaini. Hubungan Aktivitas Fisik dengan Kejadian Diabetes Mellitus Tipe 2 pada Perempuan Usia Lanjut di Wilayah Kerja Puskesmas Padang Bulan Medan Tahun 2017. J Muara Sains, Teknol Kedokteran, dan Ilmu Kesehat. 2018;2(1):78-86.

16. Pane BS. Peranan Olahraga dalam Meningkatkan Kesehatan. J Pengabdi Kpd Masy. 2015;21(79):1-4.

17. Riyadi S, Sukarmin. Asuhan Keperawatan pada Pasien dengan Gangguan Eksokrin \& Endokrin pada Pankreas. Jakarta: Graha Ilmu; 2008.

18. Almeida HFR de, Neto LS da L, Queiroga FM, Souza JA de, Paraguassú-Chaves CA, Barros J de F. Effects of an Aerobic Physical Exercise Program on Blood Glucose Levels in Type-2 Diabetic Subjects, Associated with Pharmacotherapy and Diet Therapy. Int J Adv Eng Res Sci.
2020;7(7):27-35.

19. Liubaoerjijin Y, Terada T, Fletcher K, Boulé NG. Effect of aerobic exercise intensity on glycemic control in type 2 diabetes: a meta-analysis of head-tohead randomized trials. Acta Diabetol. 2016;53(5):769-81.

20. Nojima H, Yoneda M, Watanabe H, Yamane K, Kitahara Y, Sekikawa K, et al. Association between aerobic capacity and the improvement in glycemic control after the exercise training in type 2 diabetes. Diabetol Metab Syndr. 2017;9(1):63.

21. Pan B, Ge L, Xun Y-Q, Chen Y-J, Gao C-Y, Han X, et al. Exercise training modalities in patients with type 2 diabetes mellitus: a systematic review and network meta-analysis. Int $\mathrm{J}$ Behav Nutr Phys Act. 2018;15(1).

22. Sari IP, Effendi M. Efektivitas Senam Diabetes Terhadap Kadar Gula Darah Pada Pasien Diabetes Mellitus di Lamongan. Indones J Heal Sci. 2020;4(1):50.

23. AminiLari Z, Fararouei M, Amanat $S$, Sinaei E, Dianatinasab S, AminiLari $\mathrm{M}$, et al. The Effect of 12 Weeks Aerobic, Resistance, and Combined Exercises on Omentin-1 Levels and Insulin Resistance among Type 2 Diabetic Middle-Aged Women. Diabetes Metab J. 2017;41(3):20512. 
24. Bukht MS, Ahmed KR, Hossain S, Masud P, Sultana S, Khanam R. Association between physical activity and diabetic complications among Bangladeshi type 2 diabetic patients. Diabetes Metab Syndr. 2019;13(1):806-9.

25. Haskas Y, Nurbaya S. Upaya Peningkatan Kualitas Hidup Penderita DM dengan Memberikan Pelatihan Senam Diabetes. Indones $\mathbf{J}$ Community Dedication. 2019;1(1):14-8.

26. Mahdia FF, Susanto HS, Adi MS. Hubungan antara Kebiasaan Olahraga dengan Kadar Gula Darah Penderita Diabetes Mellitus Tipe 2. J Kesehat Masy. 2018;6(5):267-76.

27. H E, Jatnika G, Nurhartini S. Pengaruh Senam Aerobik Low Impact Terhadap Kadar Gula Darah Pada Wanita Penyandang Diabetes Melitus. J Kesehat Olahraga. 2019;7(2):27584. 